Int. J. Electrochem. Sci., 15 (2020) 1310 - 1328

\title{
Nickel Hydroxide Nanoflakes Grown on Carbonized Melamine Foam via Chemical Bath Deposition for Supercapacitor Electrodes
}

\author{
Seongwoo Jeong ${ }^{1 \dagger}$, Jemoon Yun ${ }^{2}$, Nanasaheb M. Shinde ${ }^{2}$, Kyung Su Kim ${ }^{1}$, Kwang Ho Kim ${ }^{1,2, *}$ \\ ${ }^{1}$ School of Materials Science and Engineering, Pusan National University, San 30 Jangjeon-dong, \\ Geumjeong-gu, Busan 609-735, Republic of Korea \\ ${ }^{2}$ Global Frontier R\&D Center for Hybrid Interface Materials, Pusan National University, San 30 \\ Jangjeon-dong, Geumjeong-gu, Busan 609-735, Republic of Korea \\ *E-mail: kwhokim@pusan.ac.kr
}

doi: $10.20964 / 2020.02 .29$

Received: 1 October 2019 / Accepted: 27 November 2019 / Published: 31 December 2019

\begin{abstract}
$\mathrm{Ni}(\mathrm{OH})_{2}$ nanoflakes were deposited on a carbonized melamine foam $(\mathrm{CMF})$ substrate $\left(\mathrm{Ni}(\mathrm{OH})_{2} @ \mathrm{CMF}\right)$ via chemical bath deposition at room temperature. This was achieved by using three different $\mathrm{Ni}(\mathrm{OH})_{2}$ precursor solution concentrations. $\mathrm{Ni}(\mathrm{OH})_{2} @ \mathrm{CMF}-0.05$ was obtained using a $0.05 \mathrm{M} \mathrm{Ni}(\mathrm{OH})_{2}$ solution and exhibited a high specific capacitance of $1066 \mathrm{~F} \mathrm{~g}^{-1}$ at a specific current of $1 \mathrm{~A} \mathrm{~g}^{-1}$; further, this material retained a specific capacitance of $698 \mathrm{~F} \mathrm{~g}^{-1}$ at a specific current of $5 \mathrm{~A} \mathrm{~g}^{-1}$. At a scan rate of 5 $\mathrm{mV} \mathrm{s}^{-1}$, the specific capacitance of $\mathrm{Ni}(\mathrm{OH})_{2} @ \mathrm{CMF}-0.05$ was $965 \mathrm{~F} \mathrm{~g}^{-1}$. This excellent electrochemical performance is ascribed to the large amount of functional groups in CMF, which allowed for its facile reaction with $\mathrm{Ni}(\mathrm{OH})_{2}$ during the synthesis of $\mathrm{Ni}(\mathrm{OH})_{2} @ \mathrm{CMF}$ as well as with the hydroxide ions in the electrolyte during charge/discharge cycles. The monolithic device, which was achieved owing to the three-dimensional structure of CMF, delivered a high energy density of $27.5 \mathrm{Wh} \mathrm{kg}^{-1}$ at a power density of $140 \mathrm{~W} \mathrm{~kg}^{-1}$ and a high power density of $7.5 \mathrm{~kW} \mathrm{~kg}^{-1}$ at an energy density of $6.6 \mathrm{Wh} \mathrm{kg}^{-1}$. The device retained $100 \%$ of its energy density after 8000 charge/discharge cycles. This work suggests a potential approach to utilize melamine foam as a substrate for the low-cost growth of metal hydroxide nanostructures that can be used as electrode supercapacitors.
\end{abstract}

Keywords: $\mathrm{Ni}(\mathrm{OH})_{2}, \mathrm{~N}$-doped carbon, melamine foam, CBD, supercapacitor

\section{FULL TEXT}

(C) 2020 The Authors. Published by ESG (www.electrochemsci.org). This article is an open access article distributed under the terms and conditions of the Creative Commons Attribution license (http://creativecommons.org/licenses/by/4.0/). 